\title{
AUDIT SISTEM INFORMASI PELAYANAN PERPUSTAKAAN MENGGUNAKAN FRAMEWORK COBIT 5.0
}

\author{
Dwi Marisa Efendi ${ }^{1}$, Sigit Mintoro ${ }^{2}$, Iin Septiana ${ }^{3}$ \\ STMIK Dian Cipta Cendikia Kotabumi ${ }^{123}$ \\ Jalan Negara Nomor 03 Candimas Kotabumi Lampung Utara \\ Email :Dwimarisa89@gmail.com ${ }^{1}$, Sigitmintoro79@gmail.com², 1 1ins3ptiana@gmail.com ${ }^{3}$
}

\begin{abstract}
ABSTRAK
Audit pelayanan perpustakaan yang digunakan berdasarkan pada Framework COBIT 5.0 karena berfokus pada pelayanan dan permintaan layanan. Tahapan audit pelayanan perpustakaan STMIK DCC Kotabumi anatara lain yaitu Menentukan tujuan audit, identifikasi pelayanan perpustakaan dengaan Framework, analisis Capabily level, menguji kendali dan bukti-bukti dengan capabily level, verifikasi hasil, dan menyusun laporan hasil audit dan rekomendasi. Audit yang dlakukan untuk pelayanan perpustakaan berfokus pada Domain Proses DSS01 dan DSS02.
\end{abstract}

Hasil pengukuran nilai 2,5 dikarenakan indeks pembulatan nilai maka hasil berada di level 3 (established Process) yaitu saat ini proses pada setiap Domain process telah teridentifikasi dan terstandarisasi dengan baik sehingga sistem pelayanan perpustakaan stabil untuk diiplementasikan, sedangkan level yang diharapkan berada pada level 4 sehingga terjadi Gap sebesar 1,5. Untuk dapat mengatasi Gap yang ada maka dibuatlah sebuah rekomendasi yaitu agar memaksimalkan keselarasan Standart Operasional Perusahaan (SOP) perpustakaan dengan kebijakan yang berlaku.

Kata Kunci :Cobit 5, DSS01 dan DSS02, Capability Level

\section{ABSTRACT}

The library service audit that is used is based on the COBIT 5.0 Framework because it focuses on service and service requests. Kotabumi DCC STMIK library service audit stages include the determination of audit objectives, identification of library services with the Framework, Capabily level analysis, testing control and evidence with a capabily level, verifying results, and compiling reports on audit results and recommendations. Audits conducted for library services focus on the DSS01 and DSS02 Process Domains.

The measurement results of 2.5 due to the value rounding index, the results are at level 3 (established process) that is currently the process in each domain process has been identified and well standardized so that the library service system is stable to be implemented, while the expected level is at level 4 resulting in a gap of 1.5. To be able to overcome the existing gap, a recommendation is made that is to maximize the alignment of the Company's Library Operational Standards (SOP) with applicable policies.

Keywords: Cobit 5, DSS01 and DSS02, Capability Lev

1. PENDAHULUAN

Buku merupakan jendela dunia dan sumber referensi, utamanya bagi mahasiswa. Perpustakaan merupakan salah satu tempat mendapatkan buku referensi yang dibutuhkan[1] Perpustakaan berperan sebagai unit sarana perlengkapan pusat dari perguruan tinggi yang bersifat akademis dalam menunjang pelaksanaan program Tri Darma Perguruan Tinggi. Ditinjau dari proses pelaksanaanya meliputi Perpustakaan sebagai pusat pengumpulan informasi, Perpustakaan sebagai pengolahan informasi, Perpustakaan sebagai pelestarian informasi, Perpustakaan sebagai 
penyediaan pemanfaatan informasi, dan Perpustakaan sebagai penyebarluasan informasi yang relevan sebagai sumber literatur bagi suatu penelitian.[1]

Tujuh program kegiatan kerja Perpustakaan meliputi Perpustakaan sebagi pusat pelayanan informasi untuk program pendidikan dan Pengajaran, Perpustakaan sebagai pusat pelayanan informasi untuk penelitian, Perpustakaan sebagai pusat pemanfaatan dari hasil penelitian, Perpustakaan sebagai pusat informasi untuk program pengabdian pada masyarakat.[1]

Peningkatan kualitas informasi di perpustakaan dapat dilakukan dengan mengidentifikasi kebutuhan informasi, membuat stategi TI (Teknologi Informasi) dan melakuakan audit sistem informasi. Penelitian ini bertujuan untuk melakukan Audit Sistem Informasi Perpustakaan pada perguruan tinggi swasta Dian Cipta Cendekia menggunakan Framework COBIT 5.[1]

\section{METODE PENELITIAN \\ a. Sistem}

Pengertian sistem menurut Romney dan Steinbart (2015:3): Sistem adalah rangkaian dari dua atau lebih komponen-komponen yang saling berhubungan, yang berinteraksi untuk mencapai suatu tujuan.Sebagian besar sistem terdiri dari subsistem yang lebih kecil yang mendukung sistem yang lebih besar.

\section{b. Informasi}

Pengertian menurut [2]), Informasi adalah "data yang telah diorganisasi dan telah memiliki kegunaan dan manfaat".

\section{c. SistemInformasi}

Pengertian menurut [3] Sistem informasi adalah "sebuah rangkaian prosedur formal dimana data dikelompokkan, diproses menjadi informasi, dan didistribusikan kepada pemaka.

\section{d. AuditSistemInformasi}

Menurut Swastika, [4]), "Audit sistem informasi merupakan suatu cara untuk menilai sejauh mana suatu sistem informasi telah mencapai tujuan organisasi".

\section{e. PelayananPerpustakaan}

Pelayanan perpustakaan merupakan salah satu kegiatan utama di setiap perpustakaan. Pelayanan tersebut merupakan kegiatan yang langsung berhubungan dengan mahasiswa, dan sekaligus merupakan barometer keberhasilan penyelenggaraan perpustakaan.

[1]

\section{f. Audit SistemInformasi}

Audit sistem informasi adalah proses pengumpulan dan penilaian bukti - bukti untuk menentukan apakah sistem dapat memelihara integritas data, dapat mendorong pencapaian tujuan organisasi secara efektif dan menggunakan sumberdaya secara efisien.

g. Audit

Audit sistem informasi adalah proses pengumpulan dan penilaian bukti - bukti untuk menentukan apakah sistem dapat memelihara integritas data, dapat mendorong pencapaian tujuan organisasi secara efektif dan menggunakan sumberdaya secara efisien.

\section{h. COBIT (Control Objectives for Information and Related Technology)}

COBIT adalah kerangka IT governance yang ditujukan kepada manajemen, staf pelayanan IT, control departement, fungsi audit dan lebih penting lagi bagi pemilik proses bisnis (business process owners), untuk memastikan confidentiality, integrity, dan availability data serta informasi sensitif dan kritikal.[5]

COBIT 5.0 (ISACA, 2017d) membagi proses tata kelola dan manajemen IT perusahaan menjadi dua area proses utama:

a. Tata kelola (Govermance), yang memuat lima proses tata kelola, dimana akan ditentukan praktek-praktek dalam setiap proses Evaluate, Direct, dan Monitor (EDM).

b. Manajemen, memuat empat domain, sejajar dengan area tanggung jawab dari Plan, Build, Run, and Monitor (PBRM), dan menyediakan ruang lingkup IT yang menyeluruh. Domain ini merupakan evolusi dari domain dan struktur proses dalam 4.1, yaitu Align, Plan, and Organize (APO), Build, Acquare, and Implement (BAI), Deliver, Service and Support (DSS), Monitor, Evaluate, and Assess (MEA). 
Proses referensi model COBIT 5 terlihat pada gambar dibawah ini.

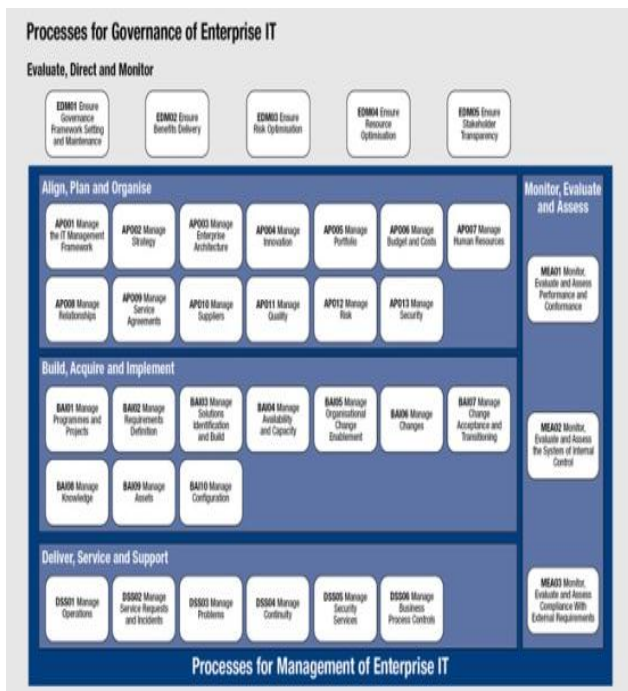

Gambar 1COBIT 5 Process Reference Model (ISACA, 2017d)

\section{i. PrinsipCobit}

COBIT 5 berdasarkan lima prinsip kunci pada gambar 2.1 untuk tata kelola dan manajemen TI (ISACA, 2012) adalah :

1. Menemukan kebutuhan stakeholder

2. Mencakup ujung ke ujung enterprise

3. Mengaplikasikan yang tunggal, mengintegrasikan framework

4. Mengaktifkan pendekatan holistik

5. Memisahkan tata kelola dengan manajemen

j. WaktuPenelitian

Dan waktu penelitian dilakukan seperti tabel di bawah ini :

Tabel 1 Jadwal Penelitian

\begin{tabular}{|c|c|c|c|c|c|}
\hline $\mathrm{N}_{0}$ & Alkifitas & April & Mei & Juni & Jull \\
\hline 1. & Sudy Pustaka & & & & \\
\hline 2. & Pengumpulan Data & & & & \\
\hline 3. & Penvebararan Kuesioner & & & & \\
\hline 4. & Perhitungan Hasil Kuesioner & & & & \\
\hline 5. & Penulisan Skripsi & & & & \\
\hline
\end{tabular}

3. HASIL DAN PEMBAHASAN

3.1 Hasil
Pada penelitian kali menghasilkan sebuah pernyataan kuesioner, dan hasil uji tingkatkemampuan sebagai berikut :

1. Hasil rata-rata pernyataan DSS01:

\begin{tabular}{|c|r|r|}
\hline Resp & D-1 & D-2 \\
\hline 1 & 3,80 & 5,00 \\
\hline 2 & 3,80 & 3,60 \\
\hline 3 & 2,00 & 2,20 \\
\hline 4 & 4,00 & 3,60 \\
\hline 5 & 4,00 & 4,20 \\
\hline 6 & 2,00 & 2,00 \\
\hline 7 & 4,00 & 5,60 \\
\hline 8 & 4,40 & 4,80 \\
\hline 9 & 4,60 & 5,60 \\
\hline 10 & 3,80 & 4,60 \\
\hline 98 & 2,00 & 1,80 \\
\hline 99 & 3,00 & 2,80 \\
\hline 100 & 4,80 & 5,20 \\
\hline 20 & 4,22 & 4,42 \\
\hline Rata -rata & 4,318416667 \\
\hline $\begin{array}{c}\text { Rata-rata Dimensi } \\
\text { 1 dan 2 }\end{array}$ & \multicolumn{2}{|c|}{} \\
\hline
\end{tabular}

Tabel 2 Hasil rata-rata pernyataan DSS01

Dari hasil pengisian kuesioner dimensi satu dan dimensi dua pada framework DSS01 di dapatkan total skor rata-rata 4,22 dan 4,42 dari 100 responden, jadi rata-rata dimensi satu dan dua adalah 4,318.

2. Hasil rata-rata pernyataan DSS02

\begin{tabular}{|c|r|r|}
\hline Resp & D-3 & D-4 \\
\hline 1 & 6,00 & 5,80 \\
\hline 2 & 4,00 & 4,20 \\
\hline 3 & 3,80 & 3,60 \\
\hline 4 & 3,60 & 3,60 \\
\hline 5 & 4,00 & 4,40 \\
\hline 6 & 4,00 & 5,00 \\
\hline 7 & 5,40 & 5,60 \\
\hline
\end{tabular}




\begin{tabular}{|c|c|c|}
\hline 8 & 5,60 & 4,60 \\
\hline 9 & 6,40 & 5,33 \\
\hline 10 & 3,80 & 4,60 \\
\hline 98 & 5,20 & 4,20 \\
\hline 99 & 4,60 & 4,40 \\
\hline 100 & 5,00 & 4,20 \\
\hline Rata -rata & 4,90 & 4,45 \\
\hline $\begin{array}{l}\text { Rata-rata Dimensi 3 } \\
\text { dan 4 }\end{array}$ & 4,6715 \\
\hline
\end{tabular}

Tabel 3Hasil rata-rata pernyataan DSS02

Dari hasil pengisian kuesioner dimensi satu dan dimensi dua pada framework DSS02 di dapatkan total skor rata-rata 4,90 dan 4,45 dari 100 responden, jadi rata-rata dimensi satu dan dua adalah 4,671 .

\subsection{Pembahasan}

\section{Capability LevelDomain Process DSS01}

Dari perhitungn capability level di dapat nilai rata-rata 2,4 (Established Process) untuk domain DSS01, jadi dapat disimpulkan bahwa kemampuan pelayanan perpustakaansudah layak di implementasikan dengan baik pada STMIK Dian Cipta Cendikia Kotabumi.

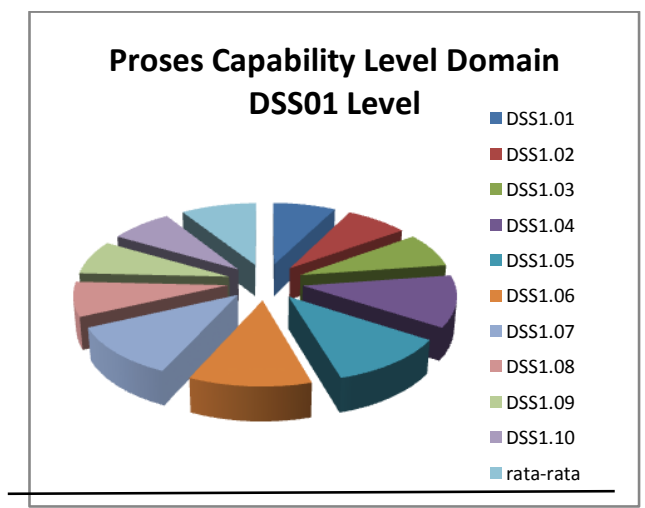

Gambar 2 Capability LevelDomain Process DSS01

\section{Capability LevelDomain Process DSS02}

Dari perhitungn capability level di dapat nilai rata-rata 2,6 (Established Process) untuk domain DSS02, jadi dapat disimpulkan bahwa kemampuan pelayanan perpustakaan sudah layak di implementasikan dengan baik pada STMIK Dian Cipta Cendikia Kotabumi. Sehingga didapatkan grafik dibawah ini :

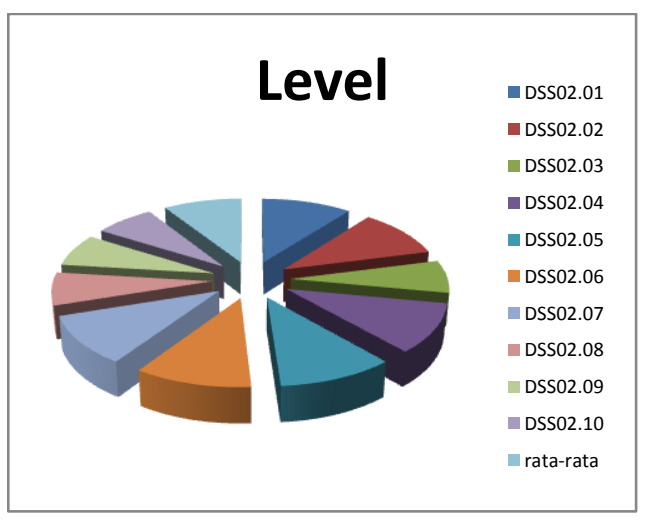

Gambar 2 Capability LevelDomain Process DSS02

\section{KESIMPULAN}

Dari hasil penelitian yang telah dilakukan pada STMIK Dian Cipta Cendikia Kotabumi terhadap pelayanan Perpustakaan yang telah diterapkan saat ini. Maka dapat diambil kesimpulan sebagai berikut :

1. Berdasarkan hasil analisis data yang dilakukan perhitungan Capibility Level dari Framework COBIT 5.0pada pelayanan perpustakaan di STMIK Dian Cipta Cendikia Kotabumi diperoleh rata-rata Proses Capability Level Domain, yaitu :

a. Pada domain proses DSS01 Menurut hasil perhitungan kuisioner didapat sebesar 4 yaitu ragu-ragu (netral), saat ini berada dlevel 2 dengan ini nilai rata-rata Capability 2,4

b. Pada domain proses DSS02 Menurut hasil perhitungan kuisioner didapat sebesar 4 yaitu ragu-ragu (netral), saat ini berada dlevel 2 dengan ini nilai rata-rata Capability 2,6

2. Diperoleh rata-rata tingkat kemampuan (Capabily Level) berada pada level 2 (managed proses) dengan rata-rata nilai 2,5 yaitu artinya pada saat ini pelayanan perpustakaan dikelola dengan baik. 
DAFTAR PUSTAKA

[1] AdiNuratmojo. 2015.Penerapan COBIT 5 Domain DSS (Deliver,Service,Support)untuk Audit Infrastruktur Teknologi InformasiFMS PT GrandIndonesia : ISSN : 2355-9365 e-Proceeding of Engineering : Vol.2, No.2 Agustus 2015.

[2] RossyRusady. 2015. Audit SistemInformasiPerpustakaanMenggunak an Domain Acquire and Implement berbasisCobit 4.1 padaperpustakaan di perguruantinggiswasta Surabaya : ISSN : 978-602-70604-2-5, Program Study MMT-ITS, Surabaya, 1 Agustus 2015.

[3] Lucia Meitarosalika.Audit SistemInformasiPerpustakaanUniversitas Kristen Petra BerdasarkanStandar Control Objectives For Information and Related Technology ( Cobit 4.0) : Surabaya 60236

[4] Wella.2016. Audit SistemInformasiMenggunakanCobit 5.0 Domain DSS pada PT Era Jaya Swasembadatbk.Program Study SistemInformasi, Universitas Multi Media Nusantara, Tanggerang, Indonesia.2016

[5] Sri BinaElshaddhani. Audit SistemInformasiInvenstoryMenggunakan KerangkaKerjaCobit 5 di PT Everlight. 2018

[6] Maria AyuPuspita. Audit InformasiKesesuaianKoleksicetakdengan KebutuhanInformasiPenggunaPadaLaya nanSirkulasi di UPT Perpustakaan, Universitas Islam Sultan Agung Semarang,Semarang, Indonesia

[7] RahmiEkaPutri. PenilaianKapabilitas Proses Tata Kelola TI Berdasarkan Proses DSSO1 Pada Framework Cobit,Teknik Informatika Program Studi Sistem Komputer FTI Universitas AndalasJl. Kampus Limau Manis Kota Padang 25163 Indonesia : ISSN: 2460738Xjuni 2016 
